\title{
ЕТЮДИ 3 МЕДИЧНОЇ ТЕРМІНОЛОГІї
}

\author{
${ }^{1}$ Львівський національний медичний університет імені Данила Галищького, \\ ${ }^{2}$ Магістр філологіі
}

А наука повинна ж поборювати звичку чекати на «укази», на «норми», а, натомість, самому досліджувати, думати, слухати інші думки $i$ висловлювати свою думку.

Лариса М.Л. Залеська-Онишкевич Наші сьогоднішні мовні проблеми, або: Що поза словом?

Роздуми 3 приводу української медичної термінології розпочинаємо з утворення термінів, що позначають запалення. Зокрема 3 терміна, що позначає запалення пазухи (sinus), приносової пневматичної, або венозної. В наш час недолугий термін «синусит» («sinusitis») майже повсюдно, також і в англомовних медичних публікаціях, витіснив граматично правильний термін «синуїт» («sinuitis»). В чому причина?

Більшість авторів сучасних підручників і посібників 3 оториноларингології отримувала середню освіту в радянській середній школі, де класичні мови не вивчалися. Тому знання латинської мови, яка $\epsilon$ основою медичного термінотворення, обмежувалися у них курсом латинської мови, яку у медичних вишах вивчали лише на першому курсі. Автор цих рядків також закінчував радянську середню школу, та, проте, встиг три роки, та й то не повні, вивчати латину в Львівській Академічній гімназії, а його професором латини (таке звання мав кожен гімназійний викладач) доктор (класичної філології) Микола Григорович Панчук, автор підручника «Scholae Latinae» 1943 року видання. I його, і підручник, напевне, пам'ятають мої молодші гімназійні товариші Борис Білинський, Юрій Шухевич. I покійний вже, на жаль, владика Лю- бомир Гузар згадував його. Мені пощастило ще й тому, що кафедрою латинської мови в Львівському державному медичному інституті впродовж 1944-1957 років керував уже згаданий викладач Микола Панчук. В інтернеті вдалося знайти лише одну згадку про нього [Панчук, 1946]. Народився 1886 року, 1912-го закінчив філософський факультет Львівського університету. Не вказується ні дата його смерті, ні місце поховання. До професора Панчука (ми, колишні гімназисти, так його і називали) я звертався за порадою, коли наступних років у мене виникали якісь сумніви щодо правильності анатомічних чи клінічних термінів.

Викликав сумнів, зокрема, широко вживаний термін, що позначав запалення пазухи - приносової чи венозної - синусит (sinusitis). Тим більше, що у підручниках та посібниках, що їх авторами були вчені 3 повною гімназійною освітою [В.I. Воячек, 1953; Л.А. Заріцький,1967; В.О. Калина, 1954; С.М. Компанєєц, 1938] цей термін звучав «синуїт». Тож, який термін правосильний? В сучасних підручниках та посібниках для медичних вишів відповіді на це не знайти. В розділах, присвячених суфіксальному термінотворенню, можна знайти твердження, що суфікс, який позначає запалення «-itis» слід додавати до кореня грецького 
(латинізованого) чи латинського іменника, що позначає орган чи тканину [П.О. Мельник та співавт., 2004], або ж до основи слова [Н.В. Дерев’ янченко, О.В. Литовська, 2017]. Але як отримати цю основу? I тут я вдамся до знань, отриманих від М. Панчука на заняттях 3 латини. Отже, основу слова отримуємо внаслідок порівняння іменника в називному (Nominativus) та родовому (Genitivus) відмінках. Те, що змінилося, відкидаємо і отримуємо основу, до якої й додаватимемо суфікс. Наприклад: Nom. «tonsilla», Gen. «tonsillae». Тут «a» змінилося на «ае», його відкидаємо і отримуємо основу «tonsill-». До неї додаємо суфікс «-itis» і отримуємо «tonsillitis». 3 іменником «sinus» дещо складніше, бо він належить до четвертої відміни чоловічого роду. I родовий відмінок не відрізняється від називного: Nom. «sinus» i Gen. «sinus». Як бути в цьому випадку? Доктор Микола Панчук пояснив: «Якщо в родовому відмінку однини нічого не змінилося, беремо для порівняння родовий відмінок множини.

\section{Singularis Pluralis}

Nom. sinus sinus

Gen. sinus sinuum

Dat. sinui sinibus

Acc. sinum sinus

Abl. sinu sinibus

Отже, порівнюємо «sinus» і «sinuиm», відкидаємо те, що змінилося, отримуємо «sinu-», додаємо суфікс «-itis» і отримуємо «sinuitis». Це все знали вчені старшого покоління і у них не викликало сумнівів, що не можна приєднувати суфікс, що позначає запалення, до відмінкового суфіксу. А я, недовчений гімназист ${ }^{1}$, мусив звертатися за консультацією до вченого латиніста. Більш пощастило співавторці ${ }^{2}$, яка, перед університетськими студіями, закінчила класичну гімназію.

Слухові кісточки, це ніжні, мініатюрні утворення. Так і хочеться називати їх зменшувальними формами іменників: молоточок, коваделко, стременце. Цієї спокуси не вдалося уникнути і М.А. Нетлюхові [Нетлюх, 1995]. А, проте, в латинській мові зменшувальна форма існує лише щодо першої $з$ них - malleus,-i $m$ - молот, колотівка, валок, обух і malleolus ,-i $m$ - молоточок. До речі, в деяких старих (XIX - початок XX століття) джерелах зустрічаємо другу 3 цих форм. А як щодо інших двох? В латинській мові - матері медичної термінології обидва терміни штучно сформовані, 3 двох слів кожний. Incus, -cudis $f$ - 3 прийменника «in», що відповідає на питання «куди» та дієслова «cudo» («cudere»), тобто «кую» («бити», «кувати», «обробляти метал»), а stapes - 3 двох іменників: statumen, -inis $n$ (підставка, опора) і pes, pedis $m$ (нога). Зменшувальні форми до них не передбачені (Дворецкий, 1976). Отже: «ковадло» і «стремено».

Coc(h)lea, ae $f$ - слимак, переважно слимак їстівний (Helix pomatia L.). Термін належить до зоогенних і всіма мовами перекладається саме так, як називається цей молюск 3 екзоскелетом, аж надто схожим 3 відповідним анатомічним утворенням. Російською - улитка, польською - ślimak, нiмецькою die Schnecke, французькою limaçon, [Кіцера, 2013], чеською - šnek (виразний вплив німецької мови). Чомусь лише в українську термінологію радянських часів введено термін «завитка», вочевидь тому, що він за звучанням ближчий до російського «улитка». Але ж завитка чи завиток - це лише один 3 обертів слимака внутрішнього вуха навколо кісткового веретена (modiolus). Значно краще звучить «закрутка» від «крутити», «закручувати», а не від «вити», «завивати». Звернімося до Бориса Грінченка [Грінченко, 1909]:

Слимак,-ка, м. 1) Улитка ... 2) Монастырский служка... 3) Писанка с изображением улитки.... В словнику української мови [СУМ, 1971-1980] значиться: «Слимак, -а,ч. Безхребетна тварина роду черевоногих молюсків». I наводяться приклади з сільськогосподарської літератури, фізіологічного журналу, з творів М. Коцюбинського та I. Франка. Як синонім вказується «равлик». У Б. Грінченка $є$ і первинний щодо зменшувальної форми, нині вже цілком забутий «равл». Далі в СУМ читаємо: «Слимак,-чка, ч - зменш. від «слимак»». В Українській Загальній Енциклопедії, відомій під назвою Коломийської [Раковський (ред.), б.р.], значиться: «Слимаки, равлики, черевоногі м'якуни з ...скрученою шкаралупкою ...».

С в третьому томі СУМ і гасло «завитка», як позначення частини внутрішнього вуха, але 3 посиланням на єдине «джерело» 
...шкільний підручник анатомії та фізіології 1957 р. У Б. Грінченка [Грінченко, 1909] «завитка» має два значення: 1) Завертка. 1. Чуб і 2) Завитка = Покритка. В українсько-російському словнику В. Кисільова [Кисільов, 1928] «улитка» перекладається як «слимак». У Е. Лукасевича [Лукасевич, 1926] «cochlea» - «слимак». А це словники, так би мовити, «передрусифікаційної ери». Отже - «слимак» і «основна закрутка слимака». А може й «равлик», як це пропонують харківські медики? [Гарюк і співавт., 2004].
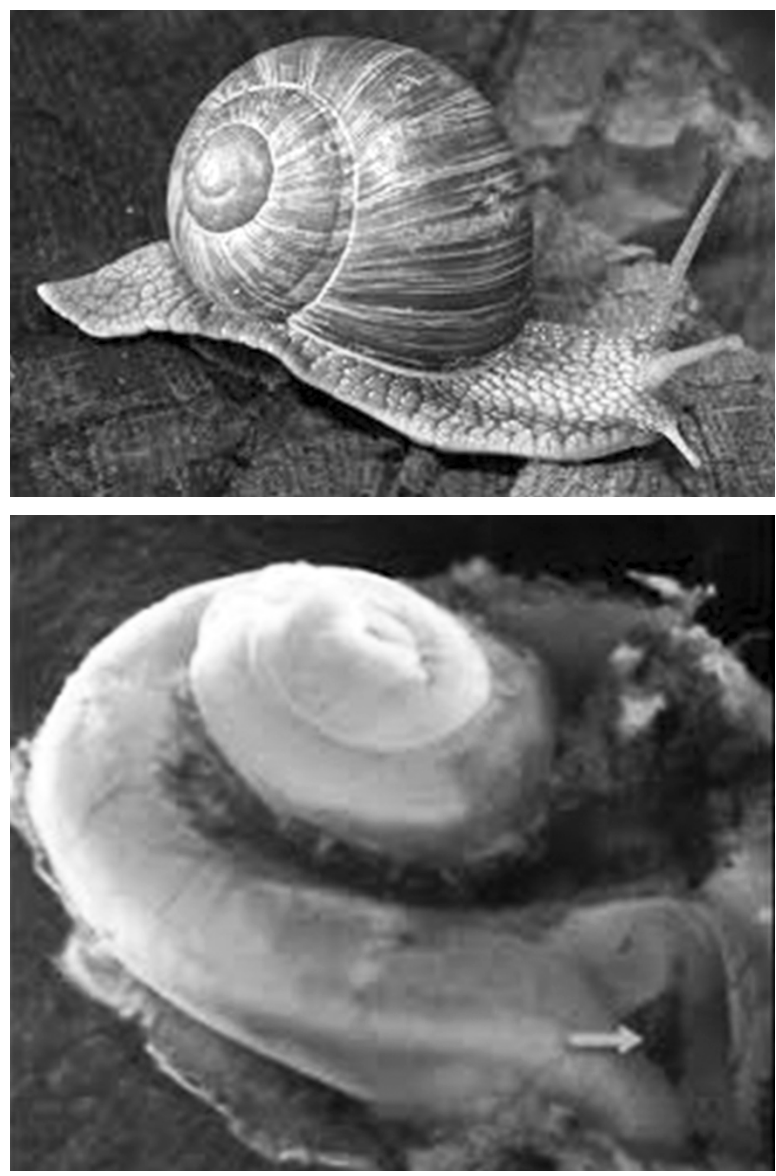

Рис. 1. Зверху - слимак виноградний, знизу - відпрепарований кістковий слимак внутрішнього вуха.

Торкаючись зоогенних термінів, не можемо обійти увагою «раковини» (передусім - вушні). У Б. Грінченка не наводиться ні раковина, ні мушля. У згаданому вище російсько-українському медичному словнику [Кисільов, 1928] «раковина» («concha») перекладається як «скойка». «Concha auriculae» - «вушна скойка». Вживався теж термін «вушниця», що нині розцінюється як невдалий варіант. Термін «мушля» $є$ в СУМ [1973 р.] з поясненням: «те саме, що черепашка». Наводяться приклади з I. Франка, Л. Первомайського, М. Коцюбинського. Власне у Михайла Коцюбинського знаходимо яскраву аналогію:

«Очі в нього горіли безсилим блиском, а вуха світились, немов рожеві мушлі» [Коцюбинський, 1955].

У Ліни Костенко [Костенко, 1989] читаємо:

«...шепотіла у мушлю вуха:

-Шy-uу-шу,

ша-ша-ша...»

А в Українській Загальній Енциклопедії [Раковський, б.р.] згадується «великий морський слимак «морське вухо» з великою гарною шкаралупою» (тобто мушлею прим. авт.).
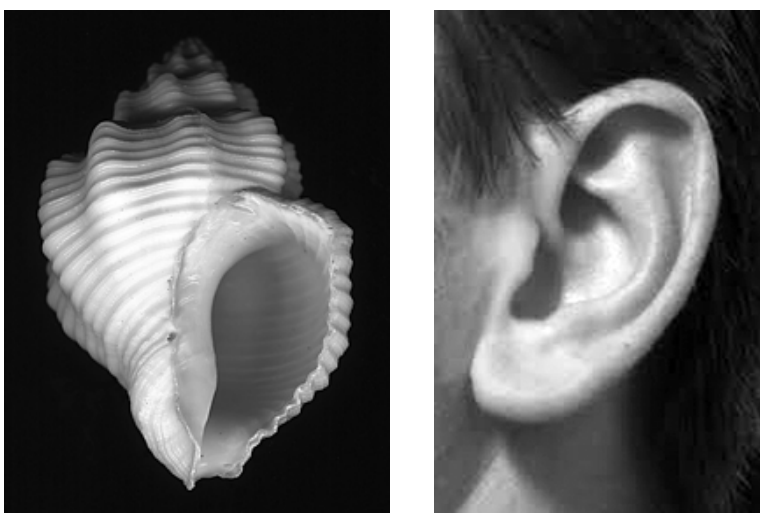

Рис. 2. Ліворуч - мушля морська, праворуч - вушна мушля.

Є ще один аргумент проти «раковини» - ятрогенічна небезпечність терміну. Як показує понад шістдесятирічна медична практика, народний вислів «раковина», здебільшого $з$ наголосом на другому “а”, це, в народному мовленні, рак, чи радше ракова хвороба.

«Напала на нього раковина - розкидало рака по всьому тілу..." (3 розмов паціснтів).

Отже вважаємо за доцільніший термін «мушля» (вушна), що ж до назви «раковина», то їі можна наводити як синонім. 


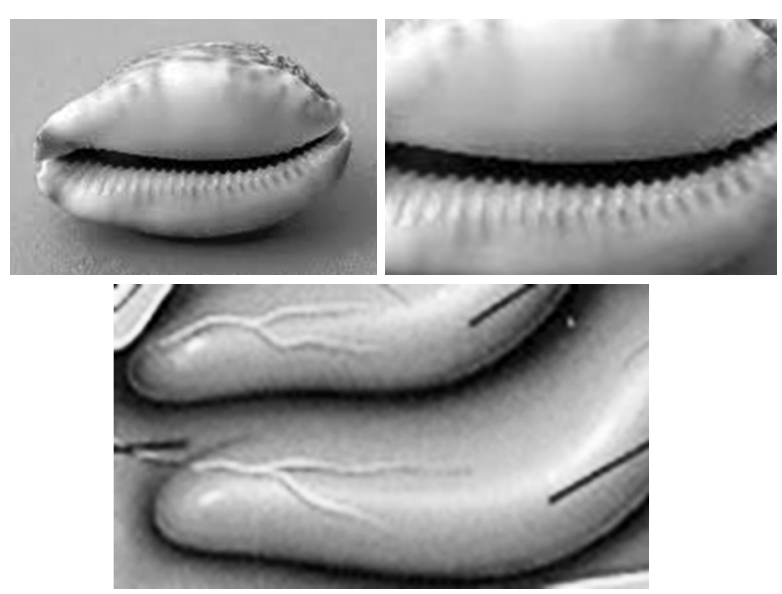

Рис. 3. Зверху - інший варіант мушлі (скойки), знизу - носові мушлі.

Про те, що українська медична термінологія розвивалася і в еміграції, свідчить такий факт. Демонструючи техніку санаційної операції на середньому вусі у своїй модифікації, доктор Богдан Макаревич (США) сказав: «A тепер розкриваємо стришок». Вражає асоціативна виразність терміну, яким колега окреслив горішню, найвищу третину барабанної порожнини.

«Стрих, -a, ч» в IV томі Нового тлумачного словника української мови НТСУМ [Яременко, Сліпушко, 1999] визначається як діалектний відповідник горища. Можна б ужити і назву «горище», але від неї неможливо утворити зменшувальну форму для окреслення цієї мініатюрної структури. Терміну «аттик», що широко вживається в оториноларингологічній літературі для позначення епітимпанум, тобто маленької куполоподібної найвищої частини барабанної порожнини ні в СУМ, ні в Новому тлумачному словнику української мови немає. В словнику іншомовних слів [Мельничук (ред.), 1974] це - «стінка над карнизом або поверх, що увінчує споруду, найчастіше - тріумфальну арку». Тож, чи не ближче українцеві поняття «горище», «стришок». ніж «аттик», особливо якщо той українець не надто обізнаний 3 архітектурою. Отже. пропонуємо писати: «епітимпанум (син. аттик, стришок)».

Маємо певні застереження і щодо анатомічного терміну «висок» i, відповідно, «вискова кістка». В НТСУМ т. I [Яременко, Сліпушко, 1999] читаємо: висок $^{1}$, -ска, ч. Те саме, що скроня; наводяться приклади з I. Франка та П. Мирного;

висок $^{2}$-ска, ч техн. Прилад, який складається 3 шнурка та підвішеного до нього тягарця і використовується для вимірювання вертикальності положення.

А в 4 томі того ж таки НТСУМ:

скроня, -i, ж/. Бокова (слід було б “бічна” - прим. автора) частина черепа від вуха до лоба: 2. Волосся, що росте на цих частинах черепа. Наводяться приклади з М. Коцюбинського, Г. Тютюнника, О. Гончара та ін. Російською “висок” перекладається як “отвес". То ж чи не краще говорити і писати “скронева кістка”, “скронева ділянка”, а "висок”, “висковий” тимчасово залишити, як синоніми.
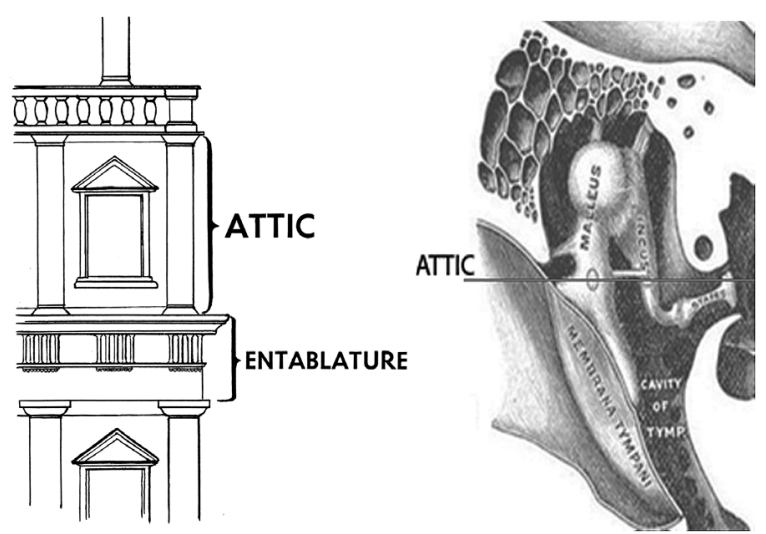

Рис. 4 Ліворуч - аттик (attic) в архітектурі - приміщення над карнизом (entablature), праворуч аттик в анатомії вуха.
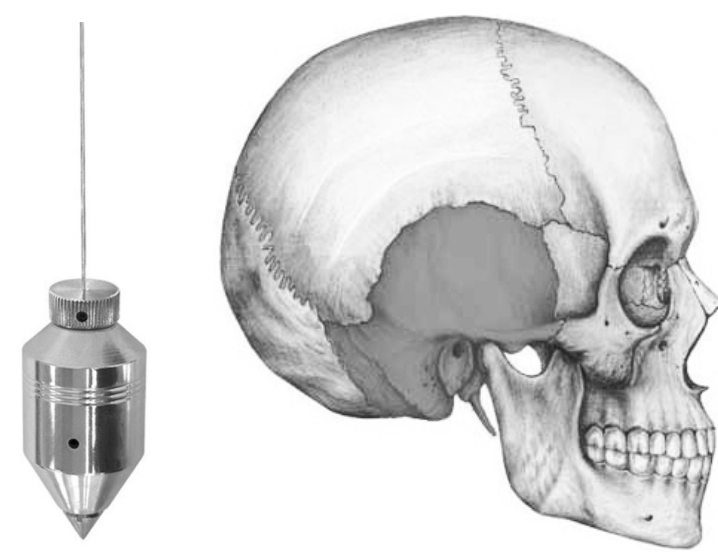

Рис. 5. Ліворуч - висок (будівельний інструмент), праворуч - скроня (скронева ділянка черепа) відповідає топографії скроневої кістки. 
Деякі, здавалось би, твердо закорінені терміни вимагають певної корекції. Передусім, як уже говорилося, ті з них, що побудовані на предметних аналогіях (аналогове термінотворення). Зокрема це стосується порівнянь $з$ ситом, решетом. «Ситоподібна плитка» - lamina cribrosa. Тут, звичайно, аналогія обгрунтована. Але ж прикметник ethmoideus $(\eta \theta \mu о \varepsilon 1 \delta \eta \zeta)$ походить від старогрецького іменника $\eta \theta \mu о \varsigma$ (решето, сито). $\mathrm{Biн,} \mathrm{як} \mathrm{і} \mathrm{українські} \mathrm{прикметники} \mathrm{«решітчас-}$ та» (кістка), «решітчастий» (лабіринт) тощо викликають у необізнаної особи уявлення пласкої двовимірної конструкції з перехресних елементів (волосіння, дротиків, штабок). Припустімо, що «решітчаста» - невдала калька 3 російської «решетчатая». В такому разі «решетка» по-українськи - «грати», отже слід було 6 писати й говорити «гратчаста кістка». I знову виникає уявлення двовимірної структури. То може нам, українцям, слід віднайти і впровадити оригінальне порівняння 3 живою природою, біоархітектонікою. Адже маємо в головному мозку ріг Амона (cornu Ammoni), чи морського коника (hippocampus). I тут щонайменше у декого 3 анатомів та оперуючих оториноларингологів спалахне думка: «Та ж ця делікатна об'ємна структура, що складається 3 тонкостінних комірочок, порожнинок, дуже нагадує бджолиний стільник (щільник)», англійською - honeykomb, латинською - favus, німецькою - die Wabe.

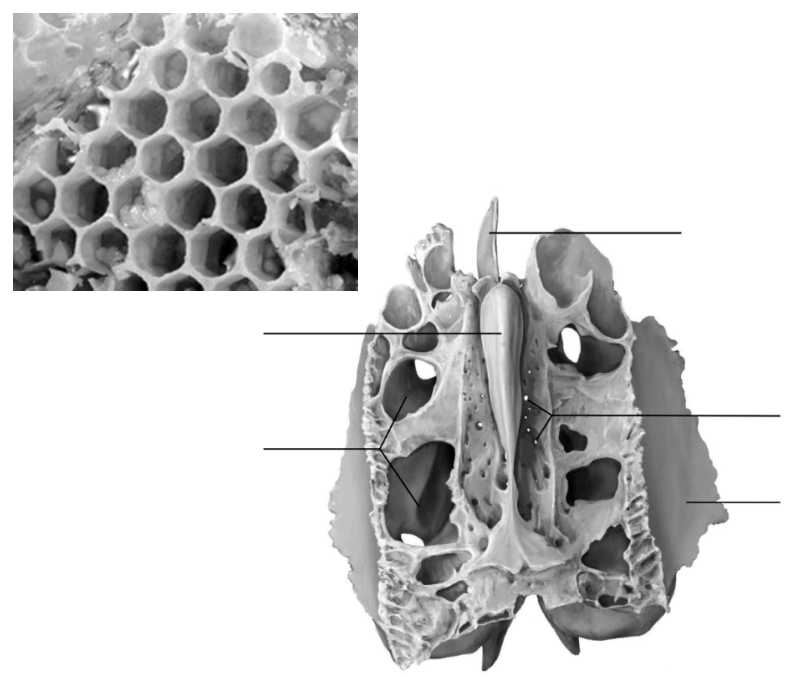

Рис. 6. Ліворуч - бджолиний стільник, праворуч решітчаста (стільникова) кістка.
Отже доцільно впровадити термін «стільникова кістка», «стільникові комірки». На науковій конференції «Актуальні проблеми української медичної термінології» (1993) цю пропозицію схвально прийняв завідувач кафедри латинської мови й основ медичної термінології Київського Державного медичного Університету (нині - Національного медичного університету імені О.О. Богомольця) професор Ю. Шанін, а також співробітники кафедри анатомії цього університету, з якими проф. Ю. Шанін [Шанін, 1993] обговорив мою пропозицію.

«Завдяки нашій зустрічі, - писав Юрій Вадимович, - ...я вперше в житті уважно роздивився оту саму гратчасту чи решітчасту кістку. I впевнився, що Ви таки маєте рацію: комірки, чарунки, стільники (щільники), але ніяк не грати, не решітка. Отже, Ваша пропозиція назвати кістку «стільник» абсолютно вмотивована візуально і структурально». Лист професора дав нам підставу впровадити термін «стільниковий лабіринт» до книг «Пропедевтика оториноларингології» [Кіцера і співавт., 1993] та «Клінічна оториноларингологія» [Кіцера, 2007], як синонім, а також використовувати його в лекціях та в повсякденному медичному мовленні. В анатомічному словнику М.А. Нетлюха [Нетлюх, 1995] ми вже знаходимо як ці, так і інші запропоновані терміни.

До речі, про комірки. Де слід вживати термін «клітина», а де «комірка»? Слово «клітина» у Б. Грінченка [Грінченко, 2009] не наводиться. Зате $\epsilon$ «комора», «комірка» $\mathrm{i}$ «Комірочка». «Клітка» наводиться 3 перекладом «клетка» (для птаха). По-німецьки $\epsilon$ лише один термін «die Zelle», що означає в російському перекладі і «клетку» і «ячейку» [Arnaudow, 1964]. Зробімо зворотний переклад 3 «ячейки». В словнику знайдемо: біол. комірка [Ганич, Олійник,1978]. Польською «komórka» - зменшувальне від «komora»приміщення, слово, споріднене 3 латинським «camera» [Левінська, Старак, 1998]. Латинською cella, ae f'- комора, кімната, тюрма [Дворецкий, 1976].

Російською «клеть» - те саме, що «komora» по-польськи й «комора» українською. У Т. Шевченка [Шевченко, 1970] читаємо: 
«У нас у костяній коморі

Горить розумний той маяк...»

(«Дурні та гордії ми люди», Кос-Арал. - 1849)

або ж

«Три года сумно протекли.

Багато дечого взяли

3 моєї темної комори...»

(«Лічу в неволі дні і ночі», Оренбург-Петербург. - 1850-1858).

Отже, і у нас (за Б. Грінченком) велике приміщення чи порожнина - «комора», а маленьке приміщення чи порожнинка «комірка» [Грінченко, 1909]. В кожному разі, щодо дрібних порожнистих утворень (в скроневій чи решітчастій - стільниковій кістці) слід вживати термін «комірка».

Неодноразово доводиться чути і читати в 3МІ «грудна клітина». Але «клітина»це щось маленьке. Латинською "cellula, ae $f$ » - комірка, мале приміщення для сторожа, келія, житло бідняка, голуб'ятня [Дворецкий, 1976]. В медичній термінології цей термін вживається щодо структурнофункціональної одиниці всіх живих організмів, будь-якого $з$ протоплазматичних утворень, що утворюють живу тканину [Мед. словник Дорланда, 2007].

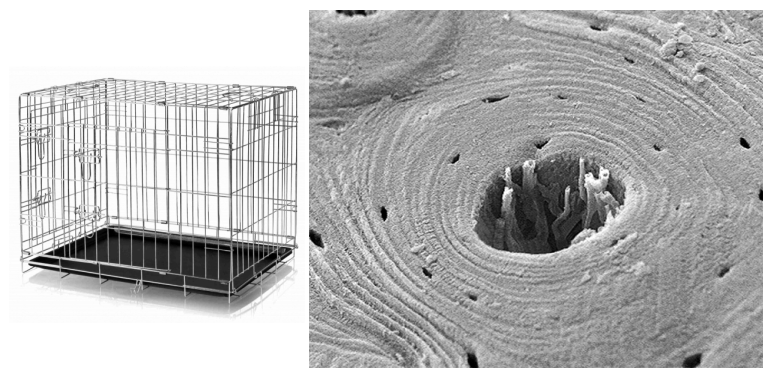

Рис. 7. Ліворуч - клітка, праворуч - клітина.

А грудна клітка, тобто «частина тіла між шиєю i діафрагмою» [Мед. словник Дорланда, 2007] - таки «клітка». Хоча цей український термін не зовсім відповідає латинському «thorax, acis m». В словнику латинської мови [Дворецкий, 1976] це нагрудний панцир з металу або шкіри. Зрештою, термін походить 3 грецької мови і

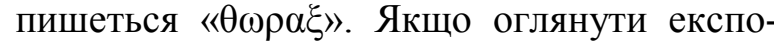
новані в музеї зброї грудні панцирі, особливо «анатомічні», тобто з ребрами жорсткості, аналогія аж надто наглядна (рис. 8). Англійською грудна клітка «chest», що, знову ж таки, не відповідає латинському «панцир». В «Великому сучасному англо-українському і українсько-англійському словнику» [Загнітко, Данилюк, 2008] «chest» скриня, шухляда. Отже «грудна скриня». Хоча на означення кісткового риштування грудної клітки вживається ще термін «гір cage» (клітка 3 ребер), або «bony thorax» [Jędraszko, 1969], а французькою - «саge thoracique» [Ганшина, 1971]. Німецьким медикам грудна клітка асоціюється 3 кошиком, тому термін звучить «der Brustkorb» (грудний кошик) [Trachtenherz, 1968; Tutsch, 1982]. Поляки солідарні з нами, українцями, принаймні грудна клітка у них таки «клітка» - «klatka piersiowa» [Łewinska, Starak, 1998]. Це ще раз підтверджує право кожного народу уточнювати анатомічні терміни згідно з властивими цьому народові уявленнями, асоціаціями.
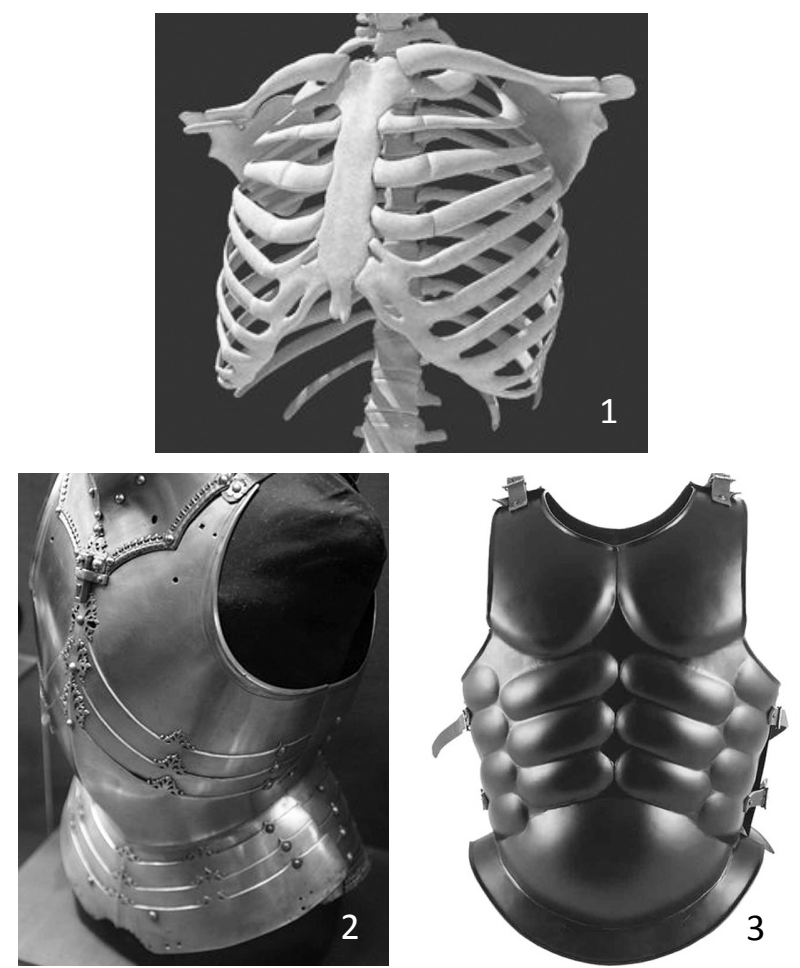

Рис. 8. 1 - кістково-хрящова грудна клітка; 2 нагрудний панцир - thorax; 3 - нагрудний панцир зразка "анатомічна кіраса" 3 "ребрами" жорсткосTi. 
«Клиноподібна пазуха» (sinus sphenoideus), чи «пазуха клиноподібної кістки» (sinus sphenoidalis) зовсім не має форми клина? Анатоми описують цю пневматичну приносову пазуху, як парну, здебільшого асиметричну порожнину у формі неправильного шестигранника. За нашими спостереженнями вона має радше полісферичну форму, зближену до шестигранника, інколи - ниркоподібну.

Отже, маємо справу з двома різними прикметниками, які походять від одного іменника бфи́vó - sphina: якісним (sphenoideus, тобто клиноподібний) і відносним (sphenoidalis - така, яка відноситься до клиноподібної пазухи). Отже кістка - os sphenoideum (клиноподібна кістка), а пазуха - sinus sphenoidalis (пазуха клиноподібної кістки).

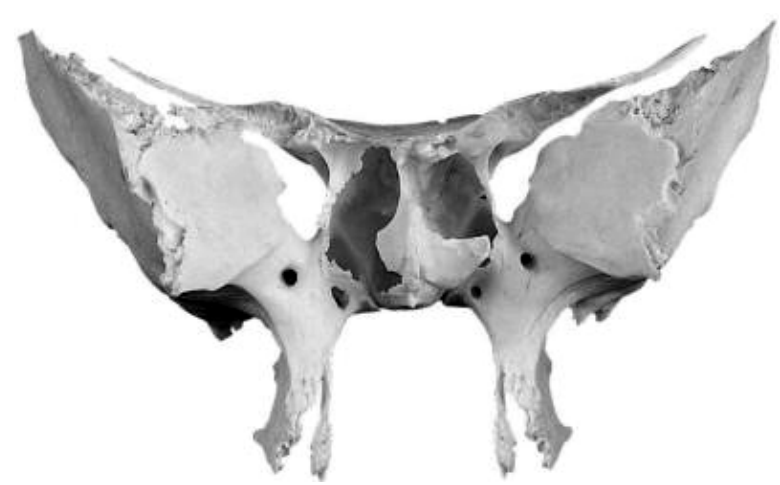

Рис. 9. Клиноподібна кістка та іï пазухи. Якщо кістка у фронтальній проекції дещо нагадує клин, то пазухи (частково збережено їх передні стінки) аж ніяк не мають клиноподібної форми.

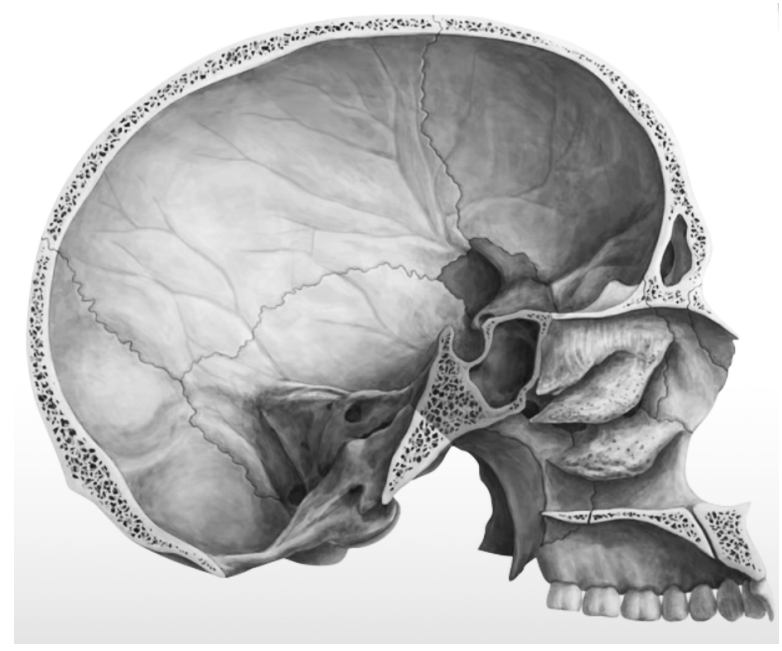

Рис. 10. На сагітальному розпилі кістка ще більшою мірою нагадує клин, проте пазуха і в цій проекції зовсім не клиноподібна за формою.
Тож пропонуємо вживати термін «пазуха клиноподібної кістки». Цю цілком обгрунтовану пропозицію ми, як автори оториноларингологічних термінів, подали до другого видання «Українсько-латинськоанглійського медичного енциклопедичного словника» 2016 року видання, проте редакція ії̈ відкинула. В семимовному «Лексиконі оториноларинголога» [Кіцера і співавт., 2013] ми наводимо термін «пазуха,-и клиноподібної кістки».

Тут варто було б нагадати правила утворення в українській мові прикметників, похідних від іменників. Утворюються вони додаванням суфікса до основи слова (отри-

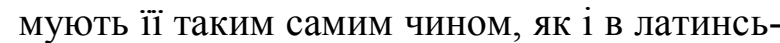
кій мові, тобто відкидаючи те, що змінилося в родовому відмінку, порівняно 3 називним). Відносні прикметники показують відношення предмета до іншого предмета, утворення, структури чи системи. Їх утворюють, додаючи до основи іменника суфікс; якщо основа закінчується на твердий приголосний, додаємо «-овий», «-ова» («казковий», «службова» тощо). Утворюючи якісні прикметники, додають здебільшого суфікс «-ний», «-на», або «-ній», «-ня» («поперечний», «поздовжня») Отже: «поперековий» (відносний до попереку, lumbalis) і «поперечний» (якісний прикметник, що показує розташування, положення, transversus). Biдповідно - «поперечний відросток поперекового хребця».

«Щелепний», чи «щелеповий»? Залежно, що маємо на увазі. «Щелеповий», якщо маємо на увазі, «належний до щелепи» (відносний прикметник), або «щелепний», якщо йдеться про якість (в зоології - наявність чи відсутність щелепи). Власне це мають на увазі зоологи, вживаючи терміни «безщелепні», «щелепні, або «щелепнороті» - gnatostomata (вищі хребетні тварини, що мають щелепи i парні кінцівки [Царик, 2013]).

Неодноразово чуємо в ЗМІ і читаємо «жовчний міхур». Якщо в російській мові «жёлчный» означає і (в прямому розумінні) вмістилище жовчі і (в переносному) особливості характеру людини, то в українській мові є два окремі терміни. Перший з них «жовчевий» означає стосунок до жовчі (відносний прикметник), другий - «жовчний» - 
характер людини чи відношення до оточення (якісний прикметник). В російськоукраїнському словнику [Ганич, Олійник, 1975] наводиться ще й термін «жёлчность» 3 перекладом «жовчність», а в II томі «Нового тлумачного словника української мови» [Яременко, Сліпушко, 1999] є пояснення цього терміну: «почуття ворожості, недоброзичливості, злоби, злість, злосливість, досада». Проте щодо міхура, то «жовчевий» прирівнюється до «жовчний». Якщо в словнику Кисільова [Кисільов, 1928] стосовно терміна «желчный (felleus)» є два переклади - «жовчевий» i «жовчний», то у М.A. Нетлюха [Нетлюх, 1995] vesica biliaris (fellea) перекладається однозначно «жовчевий міхур». Вважаю, що ці терміни слід чітко розмежовувати. I не миритися 3 такими покручами-кальками, як «головний біль». Бо ж «головний» (якісний прикметник) українською мовою означає російською «главный». А «голововий»- аж ніяк не звучить. Тому обходимося без прикметника - «біль голови». Як, зрештою, і «біль живота».

Плекати українську мову в усіх царинах науки, в тому числі - і в медичній науці - наш святий обов'язок. А праця над удосконаленням української медичної термінології - процес перманентний, як і розвиток суспільства взагалі.

\section{References}

1. Vojachec VI. [Principles of otorhinolaringology]. $4^{\text {th }}$ ed. Leningrad: Medhiz; 1953. 348 p. [In Russian].

2. Hanych DI, Olijnyk IS. [Russian-Ukrainian Dictionary]. $4^{\text {th }}$ ed. Kyjiv: Main editorial board of the Ukrainian Soviet encyclopedia; 1978. 1012 p.

3. Hanshyna KA. [Franch-Russian Dictionary]. Moscow: Russkiy yazyik; 1971. 912 p.

4. Garyuk GI, Pochujeva TV, Babanin SV, Moschenko VL. [CT in the diagnostic of middle ear diseases and otogenic intracranial complications]. Kharkiv: Prapor; 2004. 95 p. [In Ukrainian].

5. Grinchenko B, editor. [Ukrainian Dictionary]. Kyiv: Kievskaya starina; 1909.

6. Dvoretskiy IKh. [Latin-Russian vocabulary]. Moscow: Russkiy yazyik; 1976. 1096 p.

7. Derevjanchenko NV, Lytovska OV. [Latin and medical terminology]. Kharkiv: KhNMU; 2017. 172 p. [In Ukrainian].

8. Zahnitko AP, Danyljuk IH. [Contemporary English-Ukrainian and Ukrainian-English vocabulary]. Doneck: BAO; 2008. 1008 p.

9. Zaleska-Onyshkevych LVL. [Our today's language problems. That out of word?] Zbirnyk dopovidej movnoji sekciji 16 Richnoji Konferenciji Ukrain`skoji Problematyky. New York-Lviv: 1997; 12-21. [In Ukrainian].

10. Zarickyj LA. [Diseases of the ear, throat, nose]. Kyjiv: Zdorovja; 1967. 343 p. [In Ukrainian].

11. Ermolaev VG, editor. [Surgical diseases of the pharynx, larynx, trachea, bronchi and esophagus: a guide for physicians]. Moscow: Medgiz; 1954. Kalina VO. [Sinusites]; p. 834-6. [In Russian].
12. Kysilov VF. [Russian-Ukrainian medical vocabulary]. Odessa: Derzhavne vydavnytstvo Ukrainy; 1928. $172 \mathrm{p}$.

13. Kitsera A, editor. [Lexicon of otorhinolaryngologist]. Lviv: Danylo Halytsky Lviv National Medical University; 2013. 66 p. [Ukrainian-LatinRussian-English-Polish-Franch-Germain].

14. Kitsera O, Borisov O, Barilyak Y. [Propedeutics of otorhinolaryngology]. Lviv: Vilna Ukraina; 1993. 180 p. [In Ukrainian].

15. Kitsera A, editor. [Clinical otorhinolaryngology] Lviv: Kvart; 2007.531 p. [In Ukrainian].

16. Kompaniejets SM. [Inflammatory diseases of paranasal sinuses]. Kharkiv: Derzhmedvydav; 1938. [In Ukrainian].

17. Kostenko L. [Elected works]. Kyiv: Dnipro; 1989. 558 p. [In Ukrainian].

18. Kotsiubyn`skyj M. [Complete collection of works]. Kyiv: DVU; 1955. 525 p. [In Ukrainian].

19. Levinska SJ, Starak TV. [Polish-Ukrainian Dictionary]. Lviv: Svit; 1998. 304 p. [In Ukrainian, Polish].

20. Lukasevych E. [Dictionary of anatomy]. Lviv: Naukove Tovarystvo im Shevtshenka; 1926. [In Ukrainian].

21. Dorland`s Illustrated Medical Dictionary: Ukrainian-English. Lviv: Nautilus-Saunders; 2007.

22. Melnyk PO, Pishak VP, Synytsia VH. [UkrainianLatin otorhinolaryngological terminology]. Chernivtsi: Medacademija; 2009.

23. Melnychuk OS. [Dictionary of foreign words]. Kyjiv: Holovna redaktsija URE AN URSR; 1974. 865 p. [In Ukrainian]. 
24. Netlukh MA. [Ukrainian-Latin dictionary of Anatomy (Anatomical nomenclature)]. Lviv: Zhovkva; 1995. 216 p. [In Ukrainian].

25. Panchuk MG. Ukrainian book. 1946. [In Latin, Ukrainian]. Available from: https://www.worthpoint.com/worthopedia/ukrainia n-book-1946-1944330542.

26. Petrukh LI, Holovko IM. [Ukrainian-Latin-English medical encyclopaedic dictionary is in 4 volumes]. Kyjiv: Medycyna; 2012-2016.

27. Rakovskyj I, editor. [Ukrainian generaly encyclopaedia in three volumes]. Stanislaviv-Kolomyja: Ridna Shkola; 1930. 676 p. [In Ukrainian].

28. Svitlychna JI, Bazarova VI, Zhuk LG. [Clinical terminology]. Kharkiv: National University of Pharmacy; Zoloti storinky; 2006. 168 p. [In Ukrainian].

29. Bilodid IK, editor. Dictionary of the Ukrainian language: in 11 volumes. Kyiv: Naukova Dumka; 1970-1980. [In Ukrainian].

30. Tutsch D, s.a. Lexikon der Medicin. 2 Auflage. Urban \& Schwarzenberg. München-Wien-Baltimore.
31. Tsarik IV, editor. Zoology of chordates: textbook. Lviv: Ivan Franko National University of Lviv; 2013. 356 p. [In Ukrainian].

32. Shanin JV. [Letter to A. Kitsera]. [In the personal archive of author]. 14.06.1993.

33. Shevchenko T. [Works in 5 volumen]. Dnipro, Kyjiv: Publishing house of fiction "Dnepr"; 1970. [In Ukrainian].

34. Jaremenko V, Slipushko O. [New explanatory dictionary of Ukrainian]. Kyiv: Akonit; 1999. [In Ukrainian].

35. Arnaudov G. Terminologia Medica Polyglotta: Medical Terminology in Six Languages. $1^{\text {st }}$ ed. Sofija: Medicina et Physcultura; 1964. $1112 \mathrm{p}$.

36. Jędraszko S. [English-Polish and Polish-English vocabulary of medicine]. Warszawa: Państwowy Zakład Wydawnictw Lekarskich; 1958. 584 p. [In Polish, English].

37. Trachtenherz N. [German-Polish medical dictionary]. $2^{\text {nd }}$ ed. Warszawa: Państwowy Zakład Wydawnictw Lekarskich; 1968. 364 p. [In Polish, German].

\title{
ЕТЮДИ З МЕДИЧНОЇ ТЕРМІНОЛОГІї
}

\author{
${ }^{1}$ Kiйера $O,{ }^{2}$ Kiųера $P$ \\ ${ }^{I}$ Львівський національний медичний університет імені Данила Галицького \\ ${ }^{2}$ Магістр філологї \\ Email: ookitsera@gmail.com
}

Анотація

А наука повинна ж поборювати звичку чекати на «укази», на «норми», а, натомість, самому досліджувати, думати, слухати інші думки $i$ висловлювати свою думку.

\section{Лариса М.Л. Залеська-Онишкевич Наші сьогоднішні мовні проблеми, або: Що поза словом?}

Ця стаття постала на межі декількох наук: клінічної анатомії, клінічної фізіології і філології. Відповідно, її авторами є клініцист, викладач вищої школи і філолог. Автори критично аналізують деякі українські (грецько- та латинськопохідні) терміни, опираючись на джерела спеціальної літератури та красного письменства, праці філологів та власний досвід. При цьому вони на численних прикладах обгрунтовують право кожного народу впроваджувати до своєї спеціальної наукової номенклатури терміни, більш притаманні цій мові, народному побутові, співзвучні близьким цьому народові уявленням.

Автори закликають до корекції деяких українських і латинських термінів, що позначають запалення, а також - до розрізнення в клінічно-анатомічній номенклатурі прикметників, що позначають якість від тих, що позначають відношення, належність до того чи іншого предмета, утворення, явища.

Ключові слова: клінічні терміни, аналогове термінотворення, позначення запалення, суфіксальне термінотворення, якісні та відносні прикметники в медицині. 


\title{
SKETCHES OF MEDICAL TERMINOLOGY
}

\author{
${ }^{1}$ Kitsera, ${ }^{2}$ Kitsera $R$ \\ ${ }^{1}$ Danylo Halytsky Lviv National Medical University, Lviv \\ ${ }^{2}$ Magister of philology \\ Email: ookitsera@gmail.com
}

\section{Abstract}

This article appeared on the several sciences border: clinical anatomy, clinical physiology and philology. Accordingly, its authors are a clinician, a teacher of higher education and a philologist. The authors critically analyze some of the Ukrainian (Greek and Latin derivative) terms based on special literature and writing sources, philology works and their own experience. At the same time, they substantiate every nation's right to introduce terms into their special scientific nomenclature that are more common in this language, folk household, in accordance with their ideas.

The authors call for the correction of some Ukrainian and Latin terms indicating inflammation, as well as to distinguish adjectives in the clinical and anatomical nomenclature of ones that indicate quality from those indicating the relation, belonging to a particular subject, formation, phenomenon. The terms in the Ukrainian language was often formed under other languages influence and sound sometimes wrong, so it makes sense to replace some medical terms with new, correct ones. It seems like some, firmly rooted terms, require some correction. First of all, as already mentioned, those of them that are based on subject analogies (analog terminology).

To develop the Ukrainian language in all spheres of science, including medical science language is our duty. And the work on Ukrainian medical terminology improving is a permanent process, as well as the society development in general.

Key words: clinical terms, analog terminology, inflammation markings, suffixal terminology formation, qualitative and relative adjectives in medicine. 